\title{
Nitrogen cycling in a hypothetical scenario of generalised organic agriculture in the Seine, Somme and Scheldt watersheds
}

\author{
Vincent Thieu • Gilles Billen • Josette Garnier • \\ Marc Benoît
}

Received: 25 January 2010/ Accepted: 16 July 2010/Published online: 5 August 2010

(C) The Author(s) 2010. This article is published with open access at Springerlink.com

\begin{abstract}
Nitrogen contamination of ground and surface water in the Seine, Somme and Scheldt watersheds, as well as in the receiving coastal marine zones, results in severe ecological problems. Previous modelling results showed that the implementation of classical management measures involving improvement of wastewater purification and "good agricultural practices" are not sufficient to obviate these problems. A more radical scenario was therefore established, consisting of a generalised shift to organic agriculture of all agricultural areas in the three basins, with the additional constraints that livestock is fed only on local fodder production. This scenario involves an increased livestock density in the Seine and Somme and a decrease in livestock in the Scheldt basin. It leads to a significant reduction of agricultural production that finally brings the three basins closer to autotrophy/heterotrophy equilibrium. Nitrate concentrations in most of the drainage network would drop below the threshold of $2.25 \mathrm{mgN} / 1$ in the most optimistic hypothesis. The excess of nitrogen over silica (with respect to the requirements of marine diatoms) delivered into the coastal zones would be decreased by a factor from 2 to 5 , thus strongly reducing, but not entirely eliminating the potential for marine eutrophication.
\end{abstract}

Keywords Nitrogen - Organic agriculture $\cdot$ Nitrate contamination - Eutrophication $\cdot$ Seine $\cdot$ Somme $\cdot$ Scheldt

V. Thieu $(\bowtie) \cdot$ G. Billen $\cdot$ J. Garnier

UMR 7619 Sisyphe, CNRS/UPMC, 4 place Jussieu,

75005 Paris, France

e-mail: vincent.thieu@upmc.fr

M. Benoît

UR 055 INRA SAD ASTER, 662 av L. Buffet,

88500 Mirecourt, France

\section{Introduction}

For the 50 last years, the rapid development of modern agriculture in industrialised countries has considerably affected the quality of water resources, to the point of jeopardising the capacity of rural territories to produce drinking water. With respect to the early traditional agricultural systems of north-western Europe, modern agrosystems are characterised by strong decoupling of crop and animal farming. While the essence of traditional agriculture was the synergy between animal husbandry and cereal cultivation (the former providing manure to the latter) without chemical inputs, the trend is nowadays, since the last three decades, to spatially separate these two activities, some regions restricting themselves to crop production entirely sustained by synthetic fertilisation, while other regions specialise in animal husbandry largely based on the importation of fodder from distant areas. In the former regions, leaching of mineral fertilisers and herbicides has induced severe alteration of ground and surface water, while in the latter, manure produced in excess over local grass- and cropland plant growth requirements has led to considerable nitrogen and phosphorus soil surpluses and water contamination. Once transported to marine areas, nutrients in excess sustain the development of algal blooms, causing anoxia, fish kill or other harmful manifestations (Camargo and Alonso 2006; Diaz and Rosenberg 2008).

The three adjacent watersheds of the Seine, Somme and Scheldt rivers offer textbook examples of the situations described earlier. The Somme watershed, with a low population density $\left(101 \mathrm{inhab} / \mathrm{km}^{2}\right)$, is an intensive agricultural basin mostly dedicated to cereal and industrial crops. The Seine $\left(202 \mathrm{hab} / \mathrm{km}^{2}\right)$ is in the same situation as far the central Parisian basin regions are concerned, characterised 
by an increase in arable land at the expense of grassland (Mignolet et al. 2007), while mixed farming areas still exist at the eastern and western fringes of the watershed. The Scheldt basin, with a much higher population density $\left(497 \mathrm{hab} / \mathrm{km}^{2}\right)$, is characterised by very intensive animal farming activities (Table 1). Changes in nutrient export in response to human activities within these watersheds over the last 50 years are characterised by opposite trajectories for nitrogen and phosphorous. While phosphorous has recently begun a rapid decline (Billen et al. 2001, 2005, 2007), the advent of industrialised agriculture has increased the amount of nitrogen transported to coastal areas (Billen et al. 2001) or has stabilised at a higher level (Billen et al. 2005), threatening the supply of good-quality drinking water (Ledoux et al. 2007). Moreover, both the total amount and the proportions of the nutrients $(\mathrm{N}, \mathrm{P}, \mathrm{Si})$ discharged at the outlet of the three basins into the coastal zones of the English Channel and the southern North Sea are the cause of severe eutrophication of these areas, which results in massive blooms of undesirable algal species (Lancelot et al. 2005, 2007, 2009).

Recent modelling work on these three watersheds has shown that phosphate contamination will continue to go down owing to the on-going improvement of waste water P-treatment (Thieu et al. 2010). Also, the establishment of the $\mathrm{N}$ budget within the three basins (Billen et al. 2009a;

Table 1 Estimation of Anthropogenic N-autotrophy and heterotrophy of the Seine, Somme and Scheldt watersheds in the current situation (a) (as described in Billen et al. 2009a) and according to the two
Thieu et al. 2009) emphasised the minor contribution of $\mathrm{N}$ point source emissions, making diffuse agricultural sources the main target to mitigate nitrogen emission. However, implementation of current "good agricultural practices" (GAP) included in the Common Agricultural Policy, such as introduction of catch crops (like ryegrass or mustard), reduction of fertilisation rate, extensification of cattle farming would not be sufficient to meet the requirements of European regulations for both surface and groundwater contamination (Directive 2000/60/EC 2000; Thieu et al. 2010) and the balance of winter N:P ratios (Lancelot et al. 2007; OSPAR 2005). The critical delay of groundwater response to changes in agricultural practices complicates the assessment of short-term mitigation measures. The low sensitivity of nitrate contamination in the Seine aquifers to agro-environmental measures was mentioned by Ledoux et al. (2007), who showed that stopping new $\mathrm{N}$ inputs could significantly reduce nitrate concentrations, while implementing "good agricultural practices" only stabilised them on the horizon of 2050-2100.

This paper explores a more radical scenario consisting in a complete conversion of the agriculture of the three basins to organic agriculture (OA), defined, according to Stanhill (1990), as agricultural production practices "which seek to minimize the flow of inputs and outputs which sequester non renewable resources across the boundaries of the

scenarios of shifting to organic agriculture of the entire present agricultural area (b and c)

\begin{tabular}{|c|c|c|c|c|}
\hline & Seine & Somme & Scheldt & $3 \mathrm{~S}$ \\
\hline Total area $\left(\mathrm{km}^{2}\right)$ & 76,370 & 6,190 & 19,860 & 102,420 \\
\hline Agricultural area $\left(\mathrm{km}^{2}\right)$ & 50,487 & 5,237 & 13,039 & 68,763 \\
\hline $\begin{array}{l}\text { Human population density (inhab. } / \mathrm{km}^{2} \text { ) } \\
\text { (a) Present situation (Billen et al. } 2009 \mathrm{a}\end{array}$ & 202 & \multicolumn{2}{|c|}{ (a) Present situation (Billen et al. 2009a) } & 253 \\
\hline Autotrophy (kgN/km²/year) & 6,855 & 10,500 & 5,355 & 6,784 \\
\hline Livestock $\left(\mathrm{LU} / \mathrm{km}^{2}\right)$ & 15.6 & 23.3 & 69.2 & 26.5 \\
\hline Heterotrophy $\left(\mathrm{kgN} / \mathrm{km}^{2} /\right.$ year $)$ & 2,561 & 2,591 & 9,697 & 3,947 \\
\hline $\begin{array}{l}\text { Export potential }(\mathrm{A}-\mathrm{H})\left(\mathrm{kgN} / \mathrm{km}^{2} / \mathrm{year}\right) \\
\text { (b) Generalised OA scenario }(6 \mathrm{mgN} / \mathrm{l})\end{array}$ & \multicolumn{3}{|c|}{ (b) Generalised OA scenario (6 $\mathrm{mgN} / \mathrm{l})$} & 2,838 \\
\hline Autotrophy $\left(\mathrm{kgN} / \mathrm{km}^{2} /\right.$ year $)$ & 5,498 & 7,193 & 5,131 & 5,529 \\
\hline Livestock $\left(\mathrm{LU} / \mathrm{km}^{2}\right)$ & 30.5 & 38.8 & 29.8 & 30.9 \\
\hline Heterotrophy $\left(\mathrm{kgN} / \mathrm{km}^{2} /\right.$ year $)$ & 3,622 & 3,732 & 5,198 & 3,934 \\
\hline Export potential $(\mathrm{A}-\mathrm{H})\left(\mathrm{kgN} / \mathrm{km}^{2} /\right.$ year $)$ & 1,876 & 3,461 & -68 & 1,595 \\
\hline \multicolumn{5}{|l|}{ (c) Generalised OA scenario $(3 \mathrm{mgN} / \mathrm{l})$} \\
\hline Autotrophy $\left(\mathrm{kgN} / \mathrm{km}^{2} /\right.$ year $)$ & 4,583 & 5,915 & 4,296 & 4,608 \\
\hline Livestock $\left(\mathrm{LU} / \mathrm{km}^{2}\right)$ & 21.75 & 27 & 21.25 & 22.0 \\
\hline Heterotrophy $\left(\mathrm{kgN} / \mathrm{km}^{2} /\right.$ year $)$ & 2,900 & 2,768 & 4,489 & 3,200 \\
\hline Export potential $(\mathrm{A}-\mathrm{H})\left(\mathrm{kgN} / \mathrm{km}^{2} /\right.$ year $)$ & 1,683 & 3,147 & -193 & 1,408 \\
\hline
\end{tabular}

$3 S$ Seine, Somme and Scheldt watersheds 
production area", thus excluding the use of synthetically compounded fertilisers and the importation of livestock feed.

We are aware that such a scenario has a low level of short-term socio-economic realism. Although there is an increasing demand for organic food products by Western European consumers (Bonny 2006), massive conversion to organic farming does not seem to be on the current French or Belgian political agenda. Our scenario is therefore conceived more as a hypothetical and idealised one than as the assessment of a realistic management program or as an evaluation of policy changes. Our goal here is simply to evaluate the potential of a drastic change in agriculture, starting from its ability to sustain food production for local populations, but also to meet with regulation expectancies in terms of freshwater quality and coastal ecosystem health.

\section{Characterising the current $\mathrm{N}$-status of the three watersheds}

The present biogeochemical functioning of the Seine, Somme and Scheldt is characterised by a highly perturbed nitrogen cycle (Billen et al. 2009a). Three aspects of these perturbations are successively examined hereafter, in terms of the balance between production and consumption, the deterioration of freshwater quality within the drainage network, and the impact on the coastal marine eutrophication.

\section{Auto-heterotrophy status of the watershed}

Billen et al. (2009a, 2010) proposed to define the "anthropogenic N-autotrophy" of a given territory as its production of food and feed (harvested and grazed products), expressed as $\mathrm{N}$ content, and "anthropogenic $\mathrm{N}$-heterotrophy" as the $\mathrm{N}$ content of food and feed required to sustain the local population and livestock. Urban areas, where food is consumed but not produced, are obviously purely heterotrophic. Rural regions specialised in crop production are predominantly autotrophic and export nitrogen as food and/or feed, while those characterised by intensive animal farming sustained by imported feed are predominantly heterotrophic. The net commercial exportor import-of agricultural products (i.e., the surplus-or shortage — of agricultural production over the requirements of the local population and livestock) can be calculated as the balance between autotrophy and heterotrophy. The Seine and Somme basins are typical examples of autotrophic territories (Billen et al. 2009a) with a potential export of nitrogen of, respectively, 4,294 and 7,909 kgN/ $\mathrm{km}^{2} /$ year, while the Scheldt presents a high degree of heterotrophy $\left(-4,342 \mathrm{kgN} / \mathrm{km}^{2} /\right.$ year $)$. The negative value for the Scheldt watershed indicates a large flux of food and feed importation as a consequence of its high population density and its intensive livestock farming activity (Table 1a).

\section{Deterioration of freshwater quality}

As a result of the introduction of large amounts of reactive nitrogen by intensive cropping and farming activities, nitrate leaching from agricultural areas considerably affects the quality of water resources. We used the SenequeRiverstrahler model (Ruelland et al. 2007) to calculate nutrient transfers and transformations in the three drainage networks, using meteorological constraints as well as point and non-point sources of nutrient as inputs. The reference simulation is derived from Thieu et al. (2009) and corresponds to the hydrological conditions and the anthropogenic nutrient inputs of the year 2000. Running the Seneque-Riverstrahler model with these constraints allows one to calculate the resulting nitrogen concentration within the drainage network of the three basins. Figure 1a shows that the status of contamination is medium quality (i.e., $2.25-5.65 \mathrm{mgN} / \mathrm{l})$ in most areas, with the intensive agricultural zones of the central part of the Parisian basin, including the French part of the Scheldt basin presenting poor quality $(5.65-11.3 \mathrm{mgN} / \mathrm{l})$. To illustrate the critical nitrogen issue, we similarly derived inputs provided, respectively, by Thieu et al. (2010) to calculate in stream nitrogen concentration under a "good-agricultural-practices" scenario (GAP, Fig. 1b), a Pristine scenario (PR, Fig. 1e) and a Business-As-Usual scenario (BAU, Fig. 1f). The pristine scenario corresponds to completely forested watersheds, with no anthropogenic modifications of the drainage networks morphology. The BAU scenario considers the statu quo in wastewater treatment and the pursuit of the present agricultural practices with groundwater nitrate concentrations continuing to increase until they reach equilibrium with infiltrating sub-root water (Ledoux et al. 2007). It results in the worsening of surface water nitrate contamination in the central Paris basin. The GAP scenario stabilises the nitrate contamination at medium level quality.

Balance of riverine fluxes: redfield ratios and N-ICEP indicator

To assess the potential of riverine nitrogen delivery to induce coastal eutrophication, a relevant indicator is the excess of nitrogen over silica with respect to the Redfield et al. (1963) molar ratios $\mathrm{N}: \mathrm{Si}=16: 20$. Indeed, excess nitrogen delivered may lead to new production of nonsiliceous, often harmful algal blooms. The indicator of coastal eutrophication potential (ICEP: Billen and Garnier 

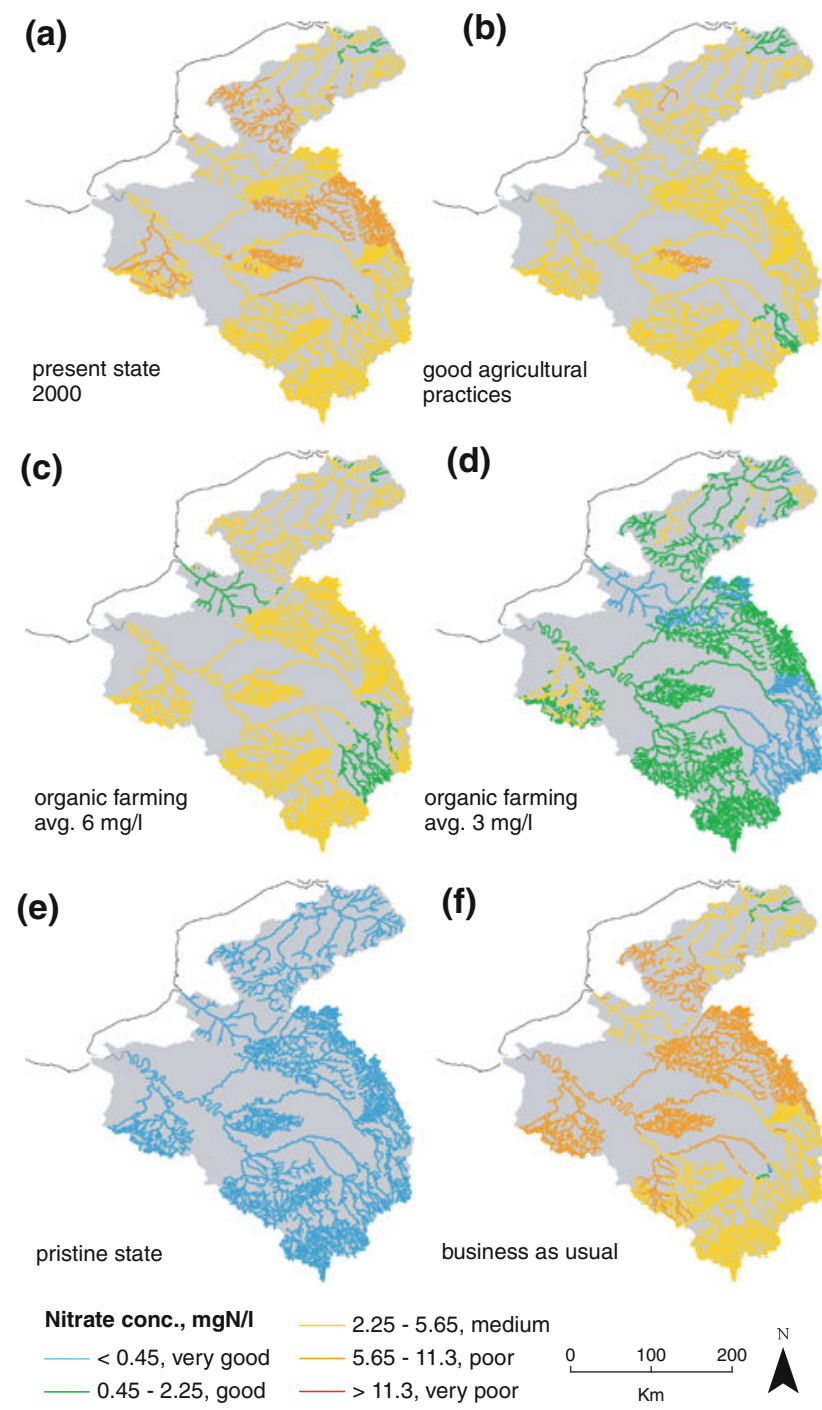

Fig. 1 Distribution of yearly mean concentration of nitrogen over the three drainage networks for different scenarios, as calculated by the Riverstrahler model. REF present situation (a), GAP good agricultural practices (b), $O A$ organic agriculture scenarios with the assumption of a sub-root nitrate concentration of $6 \mathrm{mgN} / \mathrm{l}(\mathbf{c})$ and $3 \mathrm{mgN} / \mathrm{l}(\mathbf{d}), P R I S$ pristine state (e) and $B A U$ : Business as Usual (f)

2007) defines the production of non-siliceous algae, expressed in carbon biomass units $\left(\mathrm{kgC} / \mathrm{km}^{2} /\right.$ day $)$, potentially sustained by riverine nutrient delivered in excess over silica at the coastal zone. Calculation of the N-ICEP indicator (on the basis of $\mathrm{N}$ only) for the different scenarios mentioned earlier is presented in Table 2, using the following equation:

$\mathrm{N}-\mathrm{ICEP}=[\mathrm{NFlx} /(14 * 16)-\operatorname{SiFlx} /(28 * 20)] * 106 * 12$

where NFlx, and SiFlx are, respectively, the mean specific fluxes of total nitrogen and dissolved silica (expressed as $\mathrm{kgN} / \mathrm{km}^{2} /$ day and $\mathrm{kgSi} / \mathrm{km}^{2} /$ day) delivered at the outlet of the river basins.
Table 2 Calculated values of the indicator of coastal eutrophication potential (N-ICEP) for the different scenarios considered in this paper, under dry and wet conditions

\begin{tabular}{|c|c|c|c|c|c|c|}
\hline \multirow{2}{*}{$\begin{array}{l}\text { ICEP }\left(\mathrm{kgC} / \mathrm{km}^{2} / \mathrm{d}\right) \\
\text { Hydrology }\end{array}$} & \multicolumn{2}{|l|}{ Seine } & \multicolumn{2}{|c|}{ Somme } & \multicolumn{2}{|c|}{ Schledt } \\
\hline & Dry & Wet & Dry & Wet & Dry & Wet \\
\hline $\mathrm{REF}^{*}$, present situation & 18.2 & 28.9 & 7.1 & 21.2 & 13.1 & 21.0 \\
\hline PRIS*, Pristine state & -1.8 & -4.1 & -1.4 & -4.5 & -2.8 & -5.3 \\
\hline $\begin{array}{l}\text { GAP *, Good Agric. } \\
\text { Practices }\end{array}$ & 12.4 & 19.8 & 5.5 & 14.1 & 8.9 & 12.9 \\
\hline BAU*, Business as usual & 20.2 & 34.1 & 10.2 & 27.7 & 13.9 & 22.6 \\
\hline $\begin{array}{l}\text { OA } 6 \mathrm{mg} / \mathrm{l} \text {, Organic } \\
\text { agriculture }\end{array}$ & 8.6 & 12.2 & 3.0 & 6.8 & 7.8 & 10.5 \\
\hline $\begin{array}{l}\text { OA } 3 \mathrm{mg} / \mathrm{l} \text {, Organic } \\
\text { agriculture }\end{array}$ & 5.7 & 6.2 & 1.4 & 1.9 & 5.2 & 5.8 \\
\hline
\end{tabular}

* Calculated from Thieu et al. (2010)

Negative values of the N-ICEP (as observed for Pristine condition, see Table 2 'PRIS') indicate that silica is present in excess over nitrogen, i.e., that there is "potentially" no eutrophication problem. On the contrary, positive values indicate that the amount of nitrogen is in excess of the requirement of siliceous algae, possibility leading to the development of non-siliceous (undesirable) algae.

This indicator appears to be sensitive to hydrological conditions, showing higher potential for coastal eutrophication during wet years; however, both wet and dry simulations show high positive ICEP values even for the scenarios with generalisation of 'good agricultural practices' (Thieu et al. 2010) (Table 2). This reinforces the view that additional drastic measures to control nitrogen sources from agriculture are required to control eutrophication at the coastal zone.

\section{Construction of an idealised OA scenario}

Agronomical constraints

The detailed implementation of organic farming techniques can vary greatly from one region to another, as the essence of this alternative agriculture is to adapt itself to local conditions by choosing the locally most suitable plant varieties, crop rotations and livestock species. Our idealised scenario considers that all areas of the three basins presently devoted to agriculture (both as cropland and as grassland) are converted to organic farming practices without changing the total agricultural area. The scenario implies that the only sources of fertilisation for croplands are (1) soil $\mathrm{N}_{2}$ fixation and green manure provided by legume crops inserted within rotations with cereals crops and (2) animal manure produced by livestock fed with 
locally produced grass or fodder crops (see Fig. 2). It also imposes the constraint that cattle's feeding is ensured by local production because the import of fodder is out of our hypothesis. Therefore, given a certain cattle density (in livestock units, LU), the proportion of agricultural area devoted to fodder production is calculated assuming that cattle consumption equals the sum of cattle excretion $(82 \mathrm{kgN} / \mathrm{LU} /$ year $)$ and meat/milk production $(17 \mathrm{kgN} / \mathrm{LU} /$ year) and using a mean yield of $110 \mathrm{kgN} / \mathrm{ha} /$ year for $\mathrm{N}_{2}$-fixing fodder crops. These figures correspond to the mean values currently observed in the three basins, based on official agricultural statistics (Agreste 2000; NIS 2000), and conversion coefficients (cf. Table 1, in Billen et al. $2009 \mathrm{~b})$. The area devoted to cereal cultivation is then calculated by assuming that a certain proportion of the agricultural area not devoted to fodder crops is used for $\mathrm{N}_{2}$-fixing green manure production. Theoretically, the percentage of green manure with respect to total non-fodder area may vary from 0 to $50 \%$, the latter value corresponding to a bi-annual rotation. The total $\mathrm{N}$-fertilisation of cereal cropland is then estimated using the calculated amount of livestock excreta plus green manure. The resulting production of cereal is calculated using the relationship between yield and total $\mathrm{N}$-fertilisation, observed in the three basins in the present and past situations (Fig. 3).

This procedure implicitly assumes that organic farming techniques produce yields similar to conventional agriculture, when similar levels of total (organic and mineral) fertilisation are applied. A number of studies have compared the yield of organic and conventional agriculture for

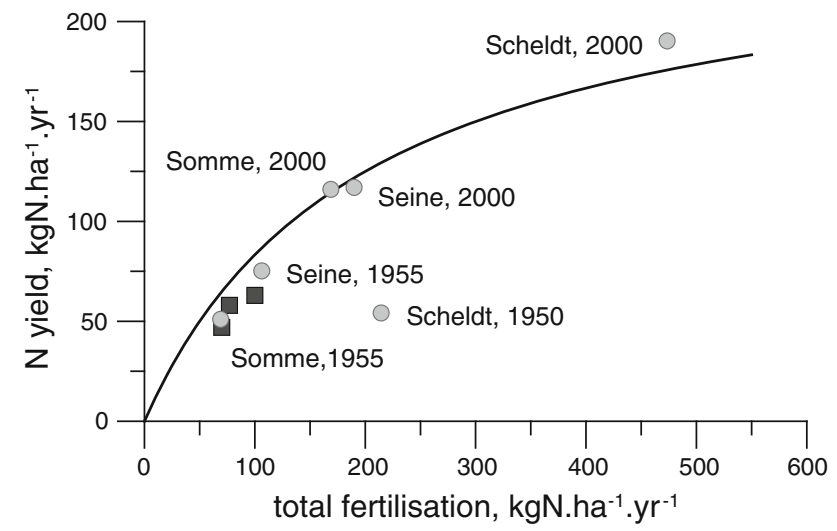

Fig. 3 Relationship observed between mean cereal crop yield and total (synthetic and organic) $\mathrm{N}$-fertilisation observed in the three basins in 2000 and 1955 (grey circles, as calculated from French and Belgian agricultural statistics). The mean yields reported for organic farms in the Centre region of France (Glachant 2009) are also plotted for comparison (dark grey squares)

different crops within the same pedo-climatic context in industrial countries (Badgley et al. 2007; Stanhill 1990): they concluded that the former is approximately a mean $10 \%$ lower than the latter. This can be explained by lower fertilisation as well as by a lower control of pests and adventices. Available detailed data for organic farms in the Centre region of France (Glachant 2009) show a crop yield versus fertiliser relationship quite similar to that established for conventional agriculture in our three basins (Fig. 3), thus supporting our assumption.
Fig. 2 Conceptual representation of the nitrogen circulation in an idealised organic agricultural system

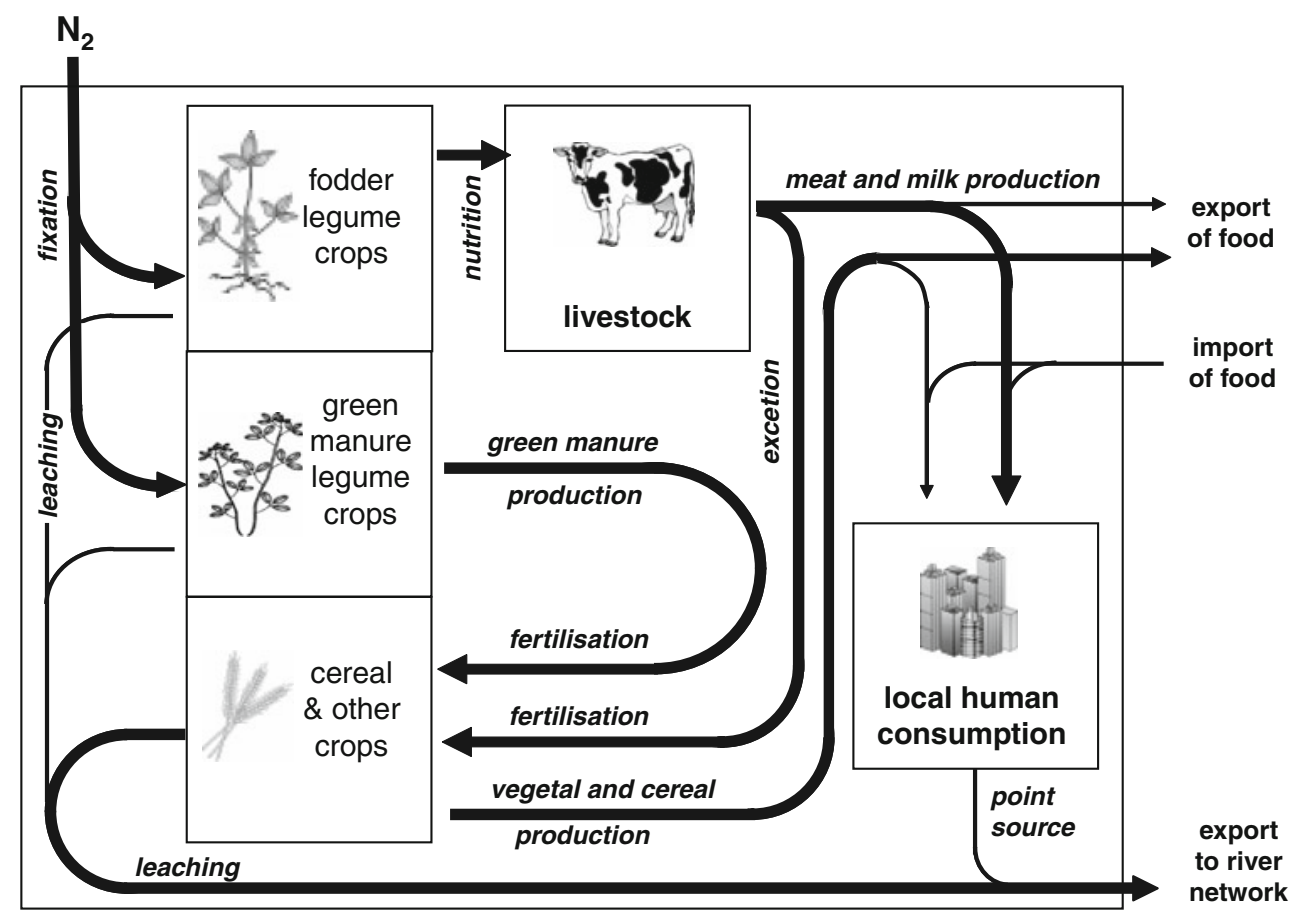


Figure $4 \mathrm{a}, \mathrm{b}$ shows the theoretical cereal yield and total cereal production calculated for the three basins as a function of livestock density and percentage of green manure used in crop successions, taking into account the constrained land allocation for fodder, green manure and cereal crops. With increasing livestock density, cereal yield increases rapidly, both because the absolute amount of fertilisation increases and because this amount is concentrated on a decreasing cropland area, which also explains why the total cereal production decreases after reaching a maximum. By comparison, the cereal yield actually observed in organic farming systems in France and Belgium ranges between 45 and $100 \mathrm{kgN} / \mathrm{ha} /$ year (FranceAgriMer 2009; Glachant 2009), thus probably restricting the realistic part of the graphs in Fig. 4a to the left half of the cattle density range.

\section{N-leaching under OA}

For the sake of evaluating the diffuse nutrient emissions of organic agriculture, we have examined the data reported in the literature concerning nitrogen concentrations in surface or sub-root water from organic farms.

Drinkwater et al. (1998) showed that substituting synthetic fertiliser with either animal or green manure to maize-soybean rotations in the north-eastern US reduced nitrate leaching by $30 \%$ and increased the soil organic matter pool. In the Bavarian Tertiary Hills region, with drained loamy soils, Honish et al. (2002) reported mean sub-root water nitrate concentration of $4.5-6.5 \mathrm{mgN} / \mathrm{l}$ for an organic farming domain, while concentrations twice as high were found in conventional agriculture. Korsaeth and Eltun (2000) compared conventional and ecological farming practices in central south-eastern Norway, including a complex rotation alternating root crops, cereal and ley. Nitrate drainage runoff was reduced from 30-35 to 20-21 kgN/ha/year, with mean nitrate concentrations in the range 4-6 mgN/l. Hansen et al. (2000) used a modelling approach to evaluate nitrogen leaching from different organic farming systems (including arable crop, pig and dairy-beef production) in Denmark on both loamy and sandy soils. The calculated mean nitrate concentration under the root zone varied in the range of 7.7-14 $\mathrm{mgN} / \mathrm{l}$ for sandy soils and 5.5-8.6 mgN/1 for loamy soils. For the entire experimental INRA domain of Mirecourt (East of Parisian Basin, France), which has been reconverted into organic farming since 1994, Benoît and Larramendy (2003) calculated the mean nitrate concentration of drained water, based on measurements in suction-pipes, to $5.5-6.5 \mathrm{mgN} / 1$, about half being caused by the ploughing of temporary alfalfa meadows used in the crop rotation before cereals. All these data converge toward a range of $3-6 \mathrm{mgN} / \mathrm{l}$ as a reasonable value for the mean nitrate concentration in the sub-root water produced by organic agriculture. This range will be used in our scenario to define the diffuse sources of nitrate. Interestingly, this is exactly the range (3.4-5.8 $\mathrm{mgN} / \mathrm{l})$ reported by Sabatier (1890) for the agricultural systems of the Paris basin at the end of the nineteenth century.

To check the consistency of this range of concentrations with the agronomical constraints discussed in the preceding section, we calculated the nitrogen losses from arable land as the excess of $\mathrm{N}$-fertilisation over $\mathrm{N}$ crop uptake; we then converted it into maximum sub-root nitrate concentration considering the mean annual runoff values of the respective watersheds, namely $260 \mathrm{~mm}$ for the Seine, $240 \mathrm{~mm}$ for the Somme and $330 \mathrm{~mm}$ for the Scheldt (Thieu et al. 2009). This approach obviously ignores the possible other losses through denitrification and ammonia volatilisation at the plot scale; more specifically, these loss processes are lumped within a landscape retention term of the SenequeRiverstrahler model as discussed elsewhere. For pastures and green manure areas, a mean nitrogen loss of $5 \mathrm{kgN} / \mathrm{ha} /$ year was considered based on observations reported by Benoît et al. (1995). The resulting mean nitrate sub-root concentration at the scale of these mixed-agricultural areas calculated for the three basins as a function of livestock density and green manure proportion are shown in Fig. 4c. Setting the proportion of green manure in succession to a value of $25 \%$, the above-discussed range of 3-6 mgN/l for sub-root nitrogen concentrations defines the allowed range of cattle densities to 22-30, 27-39 and 21-29 LU/ $\mathrm{km}^{2}$ for the Seine, Somme and Scheldt, respectively.

\section{Other constraints to the OA scenario}

As for groundwater concentration, we will assume in this idealised scenario that aquifers have reached equilibrium with the infiltrating sub-root water concentration. As this equilibrium can require as long as 50 years, our scenario thus represents the long-term effect of organic agricultural practices. The Seneque-Riverstrahler model considers a landscape (or riparian) nitrate retention term, expressed as a percentage of nitrate flux emitted from the watershed at the plot scale. This term was assumed to be the same as in the reference scenario (Thieu et al. 2009). The scenario considered here uses the same hydrological constraints as in the latter study, namely those of a wet, a mean and a dry year (2001, 2000 and 1996, respectively). The point sources of nutrients (inputs of urban wastewater) correspond to the scenarios defined in Thieu et al. (2010) with $90 \% \mathrm{P}$ removal and $70 \% \mathrm{~N}$ removal in all wastewater treatment plants with capacity over 20,000 inhabitant equivalents.

Data on the role of organic farming practices on the emissions of other nutrients (phosphorous, silica) and suspended matter are too scarce to support any hypothesis 
Fig. 4 Theoretical $\mathrm{N}$ yield of cereal (and other non- $\mathrm{N}_{2}$-fixing) crops (a), production of cereal crops (b) and nitrate sub-root concentration (c) as a function of organic fertilisation, here represented by cattle density (manure) and the proportion of non-fodder area devoted to legume crops (green manure) in the Seine, Somme and Scheldt watersheds. The calculation considers no change with respect to the current total agricultural area of the basins
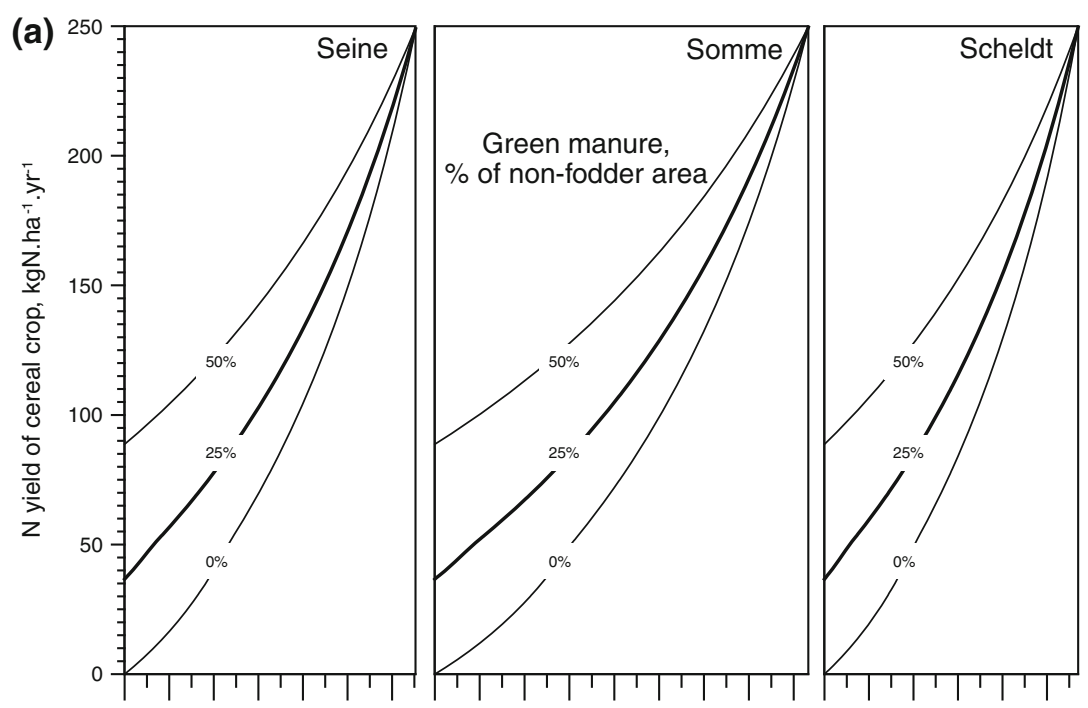

(b)
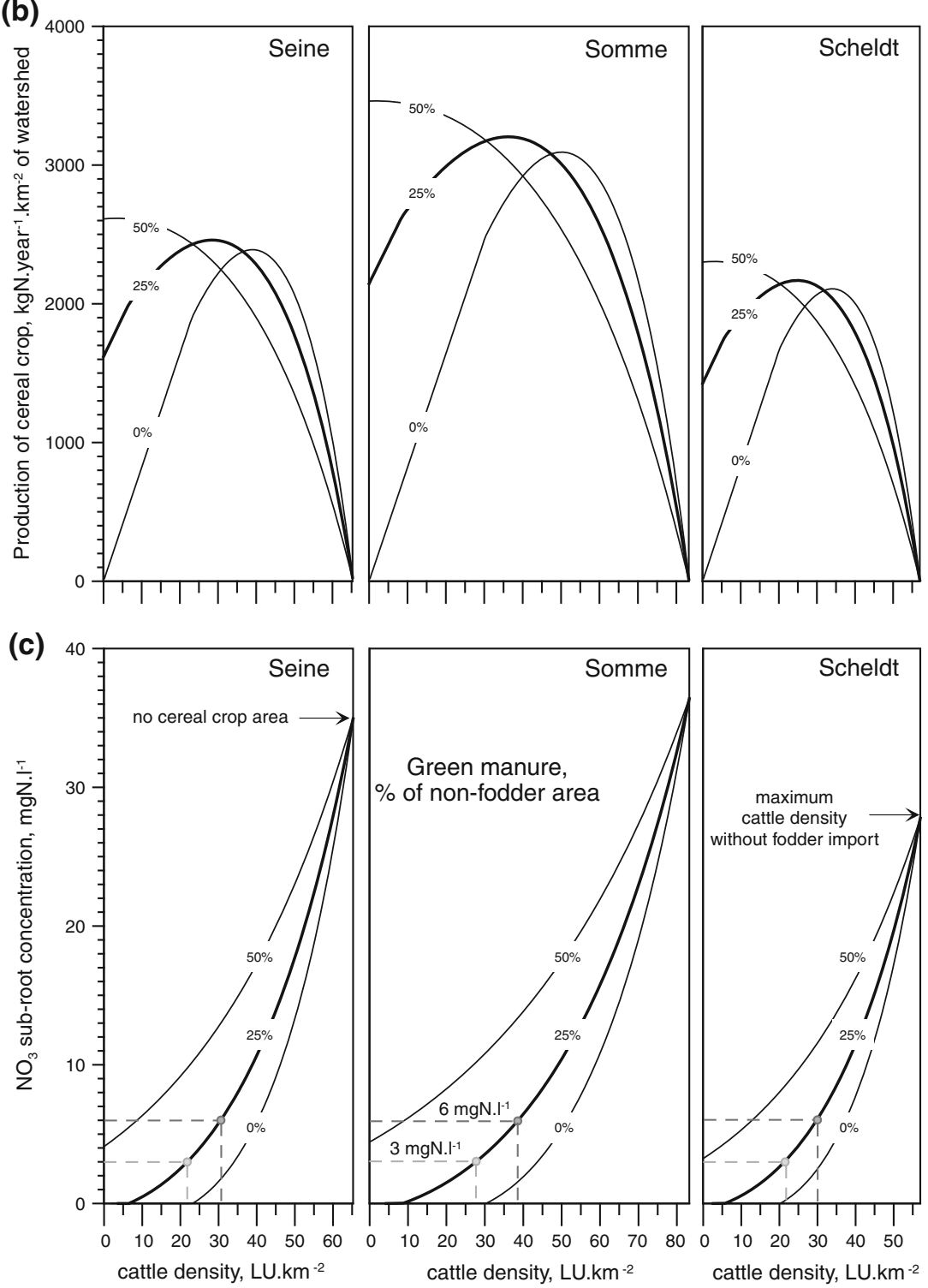
about a change with respect to the presently observed situation, so that we have assumed the same diffuse sources for these nutrients as those discussed by Thieu et al. (2009).

\section{Results}

We here present the results of our idealised OA scenario, based on the three indicators used above to characterise the present situation in terms of balance between autotrophy and heterotrophy, freshwater quality in the drainage network, and impact on the coastal marine eutrophication. The results will also be compared with those of the previously described "pristine", "business as usual" and "good agricultural practices".

Reducing the gap between autotrophy and heterotrophy

Our organic farming scenario involves a significant reduction of agricultural production in both the Seine and the Somme basins, with a simultaneous increase in livestock density and heterotrophy (Table 1a, b, c). The Seine watershed becomes nearly equilibrated in terms of autotrophy (A) and heterotrophy $(\mathrm{H})$, with only a small export of agricultural products, ranging from 1,680 to $1,880 \mathrm{kgN} /$ $\mathrm{km}^{2} /$ year, respectively, for the 3 and $6 \mathrm{mgN} / \mathrm{l}$ sub-root concentration scenarios. The Somme watershed can still export a larger part of its agricultural production (from 3,150 to $3,460 \mathrm{kgN} / \mathrm{km}^{2} /$ year). In the Scheldt basin, agricultural production remains about the same, but the livestock density is greatly decreased from $70 \mathrm{LU} / \mathrm{km}^{2}$ in the current situation to less than $30 \mathrm{LU} / \mathrm{km}^{2}$ in our organic farming scenarios. However, due to its high human population density, the Scheldt remains a heterotrophic basin, importing from 60 to $190 \mathrm{kgN} / \mathrm{km}^{2} /$ year as food and feed. The trends corresponding to our scenario are represented in Fig. 5 as an ANAH diagram ('Anthropogenic Nitrogen Autotrophy and Heterotrophy', see Billen et al. 2010), which also shows the long-term historical trajectories of the three basins. The organic agriculture scenario corresponds to the reversal of the trends observed during the last 30-50 years, and the return toward a closer balance between autotrophy and heterotrophy.

In addition to the overall status of autotrophy/heterotrophy, the satisfaction of human needs in terms of both animal and plant proteins should be assessed. The human daily $\mathrm{N}$ intake per capita in France and Belgium is estimated at $15 \mathrm{gN} /$ inhab/day, with a share of animal products (meat, milk and eggs) of about 65\% (FAOstat 2006). The share of animal and cereal production implied by the construction of our organic agriculture scenario does not match this pattern. Regarding the cereal production by organic farming, although it would decrease in average by

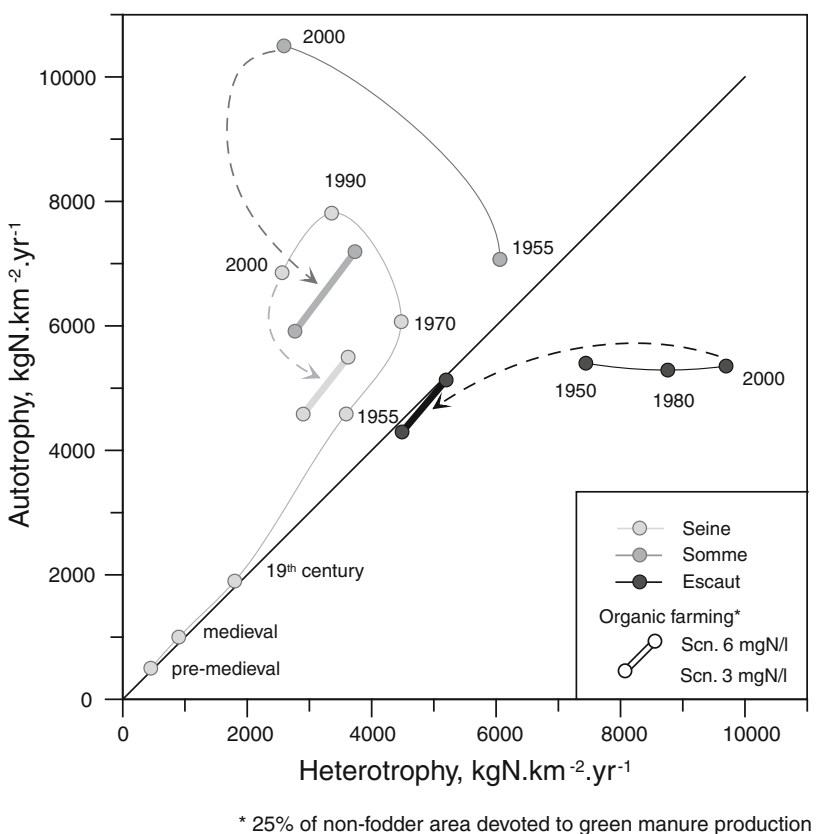

Fig. 5 Anthropogenic nitrogen autotrophy and heterotrophy of the three basins based on the assumption of a shift to organic agriculture. The range for the two OA scenarios defined is shown (see also Table 1) and compared with the present and historical situations (Billen et al. 2009a, b)

a factor of 3 with respect to their level in the current situation, this production remains in large excess compared to the consumption of the local population (Table 3). However, as far as animal products are concerned, the present conventional agriculture system, except within the Somme basin, does not cover the demand of local populations for meat and milk, which is presently largely imported from distant specialised areas. Our organic agriculture scenario slightly improves the self-sufficiency for animal products in the Seine basin $(52-73 \%$ for the respective organic scenarios, compared with the current $37 \%$ value), while for the Scheldt basin the percentage of satisfaction of meat and milk demand decreases (21-29\% for the organic scenarios, compared with a present level of $67 \%$ ).

Improving the quality of the drainage network

Thieu et al. (2010) have demonstrated that improvement of urban waste water treatment in the Seine, Somme and Scheldt basins has a much greater effect on the restoration of phosphorus quality than on nitrogen because of the dominant part of diffuse sources in the total $\mathrm{N}$ loading. The short-term outcomes of the implementation of good agricultural practices would be a decrease in nitrogen surface runoff fluxes with respect to the reference 2000 scenario by 32,40 and 35\%, respectively, for the Seine, Somme and Scheldt (Thieu et al. 2010). In our organic agriculture 
Table 3 Human food production and consumption of the Seine, Somme and Scheldt watersheds in the current situation (a) and in the two organic agriculture scenarios considered (b and c)

$\frac{\text { Seine }}{\text { Needs Prod. (\% needs) }} \frac{\text { Somme }}{\text { Needs Prod. (\% needs) }} \frac{\text { Scheldt }}{\text { Needs Prod. (\% needs) }} \frac{3 S}{\text { Needs Prod. (\% needs) }}$

\section{(a) Present situation}

\begin{tabular}{|c|c|c|c|c|c|c|c|c|}
\hline Cereal (and vegetables) $\left(\mathrm{kgN} / \mathrm{km}^{2} /\right.$ year$)$ & 387 & $6,189(1,676 \%)$ & 194 & $9,524(4,921 \%)$ & 950 & $5,535(582 \%)$ & 485 & $6,264(1,293 \%)$ \\
\hline Meat and milk (kgN/km²/year) & 719 & $267(37 \%)$ & 359 & $484(135 \%)$ & 1,765 & $1,189(67 \%)$ & 900 & $459(51 \%)$ \\
\hline \multicolumn{9}{|l|}{ (b) Generalised $\mathrm{OA}(6 \mathrm{mgN} / \mathrm{l})$} \\
\hline Cereal (and vegetables) $\left(\mathrm{kgN} / \mathrm{km}^{2} /\right.$ year) & 387 & $2,460(636 \%)$ & 194 & $3,211(1,659 \%)$ & 950 & $2,137(225 \%)$ & 485 & $2,443(504 \%)$ \\
\hline Meat and milk $\left(\mathrm{kgN} / \mathrm{km}^{2} /\right.$ year $)$ & 719 & $522(73 \%)$ & 359 & $804(224 \%)$ & 1,765 & $512(29 \%)$ & 900 & $537(60 \%)$ \\
\hline \multicolumn{9}{|l|}{ (c) Generalised $\mathrm{OA}(3 \mathrm{mgN} / \mathrm{l})$} \\
\hline Cereal (and vegetables) $\left(\mathrm{kgN} / \mathrm{km}^{2} /\right.$ year) & 387 & $2,417(624 \%)$ & 194 & $3,141(1,623 \%)$ & 950 & $2,157(227 \%)$ & 485 & $2,410(497 \%)$ \\
\hline Meat and milk (kgN/km²/year) & 719 & $372(52 \%)$ & 359 & $560(156 \%)$ & 1,765 & $365(21 \%)$ & 900 & $382(42 \%)$ \\
\hline
\end{tabular}

$3 S$ Seine, Somme and Scheldt watersheds

scenario, this reduction over the short term reaches 54-73, 63-78 and 49-70\% for the three basins, respectively, when testing the range of 3-6 $\mathrm{mgN} / 1$ for the mean nitrate concentration in the sub-root water produced by organic agriculture. Under the same assumptions, the groundwater concentrations would decrease by $24-58,39-67$ and $13-51 \%$ for the three basins, respectively, in the OA scenario. By comparison, in the business-as-usual scenario, the groundwater nitrogen fluxes to the drainage network increases (by $82 \%$ in the Seine, $78 \%$ in the Somme and $77 \%$ in the Scheldt) due to the equilibration of groundwater concentrations.

Figure 1c and d show that the impact of good agricultural practices is essentially significant in the more damaged regions (Brie-Beauce for the Seine, Upper Scheldt) restoring medium water quality, except in small residual poor-quality areas. However, the (long term) assumption of a $6 \mathrm{mg} / \mathrm{l}$ (Fig. 1c) mean nitrate sub-root concentration with organic agriculture restores all poor-quality areas and results in a shift from medium to good water quality (0.45-2.25 $\mathrm{mgN} / \mathrm{l})$ for the Somme and the upstream basins of the Seine, which combine forest and agricultural use. By considering a lower sub-root nitrate concentration (3 mg/l), these areas become very good $\left(<0.45 \mathrm{mg} \mathrm{N}-\mathrm{NO}_{3} / \mathrm{l}\right)$, and most of the three drainage networks gain good quality (Fig. 1c). Such an organic agriculture scenario is the only one tested able to achieve the good quality status in the downstream part of the three rivers. Only the pristine state scenario (Fig. 1e) produces better quality to the entire drainage networks, although this obviously does not represent a realistic target, as it ignores any human influence. At the other extreme of this prospective exercise, the business-as-usual scenario (Fig. 1f) shows severe worsening of freshwater contamination, characterised by an overall poor quality in the lower Seine River and several of its tributaries. All these results support the urgent need to mitigate nitrogen emissions.

Limiting the potential for coastal eutrophication

For mean hydrological conditions (based on the year 2000), present reference nitrogen fluxes exported from the Seine to the sea are estimated at $1,975 \mathrm{kgN} / \mathrm{km}^{2} /$ year (Fig. 6). This amount of nitrogen delivered decreases to 1,462 , 1,084 and $768 \mathrm{kgN} / \mathrm{km}^{2} /$ year, respectively, for the shortterm good agricultural practices scenario (GAP) and the two long-term organic agriculture scenarios (OA3 and OA6), while the business-as-usual simulation provides a flux of 2,245 kgN/ $\mathrm{km}^{2} /$ year. For the Somme, characterised by a reference flux of $1,333 \mathrm{kgN} / \mathrm{km}^{2} /$ year, these changes in agricultural practices reduce nitrogen export values to 987,663 and $436 \mathrm{kgN} / \mathrm{km}^{2} /$ year, respectively, while $1,623 \mathrm{kgN} / \mathrm{km}^{2} /$ year is reached for the business-as-usual scenario (BAU). In the Scheldt, the smaller gap between surface and groundwater contaminations makes the BAU simulation $\left(1,570 \mathrm{kgN} / \mathrm{km}^{2} /\right.$ year $)$ closer to the current situation $\left(1,464 \mathrm{kgN} / \mathrm{km}^{2} /\right.$ year$)$. The impact of good agricultural practices (GAP) is comparable to the effect of organic agriculture, with fluxes estimated, respectively, at 1,071 and $974 \mathrm{kgN} / \mathrm{km}^{2} /$ year. A further decrease, to $737 \mathrm{kgN} / \mathrm{km}^{2} /$ year, is simulated assuming a mean nitrate concentration of $3 \mathrm{mgN} / \mathrm{l}$ below the root zone of arable soils in organic agriculture. Thus, whatever the hydrological conditions are, organic agriculture appears as the most efficient scenario. It significantly reduces nitrogen fluxes by a factor of $2-3$ at the outlet of the three basins. In comparison, the implementation of good agricultural practices reduces it by a factor of only 1.4.

The variability of nitrogen-diffuse sources depending on the hydrological conditions explains greater N-ICEP values 

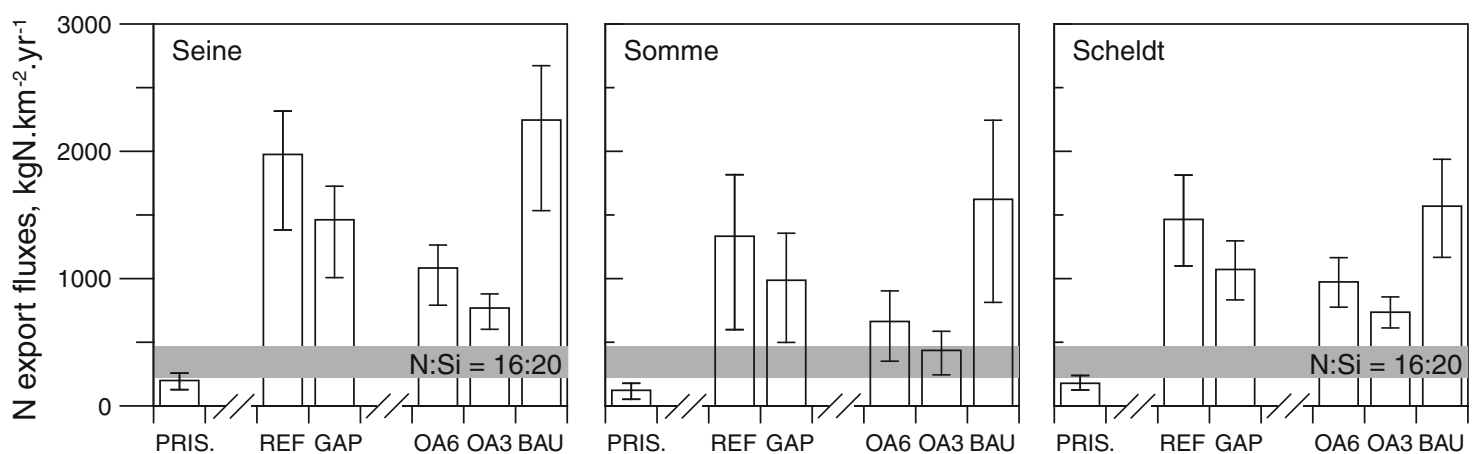

Fig. 6 Mitigation of the nitrogen fluxes exported to the coastal zone by the Seine, Somme and Scheldt rivers. Calculation made by the Seneque-Riverstrahler model for mean (central symbol), dry (negative bar plot) and wet (positive bar plot) hydrological conditions.
$P R I S$ pristine scenario, $R E F$ present situation, $G A P$ good agricultural practices scenario, $B A U$ business-as-usual scenario, OA6 and OA3: generalised organic agriculture scenario with a mean of 6 and $3 \mathrm{mgN} /$ 1 in sub-root water of agricultural land respectively

Our results are valuable in the context of the recent during wet years for all scenarios (Table 2). The receiving coastal waters of the three basins are currently characterised by a high potential for eutrophication, with the N-ICEP value ranging for present situation 'REF' from 21 to $29 \mathrm{kgC} / \mathrm{km}^{2} /$ day under wet hydrological conditions, while the business-as-usual scenario increases these values to $23-34 \mathrm{kgC} / \mathrm{km}^{2} /$ day. Good agricultural practices (GAP) would decrease the N-ICEP by wet conditions to $13-20 \mathrm{kgC} / \mathrm{km}^{2} /$ day, while the two organic agriculture scenarios would reach N-ICEP values as low as 6-12, 2-6 and $6-10 \mathrm{kgC} / \mathrm{km}^{2} /$ day for the Seine, Somme, Scheldt, respectively, thus representing a quite significant reduction of the potential to sustain harmful algae development in the coastal area.

\section{Discussion}

The scenario discussed in this paper was developed after having concluded that realistic mitigation measures (improvement of wastewater treatment and so-called good agricultural practices) are not radical enough to obviate the environmental problems caused by nitrogen contamination of ground, surface and coastal waters. By constructing a scenario based on generalised organic farming practices at the scale of these three highly populated European watersheds, we were willing to test whether agriculture, by essence, can conciliate (1) the demand for food and feed by local populations, (2) a good ecological functioning of aquatic ecosystems and (3) a balanced nutrient status for the adjacent coastal area.

For the first point, it clearly appears that organic farming scenarios hold a closer equilibrium between autotrophy and heterotrophy, even though it preserves the original status of the three basins, with the Somme remaining the most autotrophic territory, while the Scheldt stands with a shortfall in production with respect to its consumption needs. controversy about the capability of organic agriculture to "feed the world" (Badgley and Perfecto 2007; Connor 2008). As a whole, the territory covered by the three basins-Seine, Somme and Scheldt-covering one of the most populated areas of the world, can largely produce the proteins required for human and animal consumption through organic farming, leaving even an exportable surplus of over $1,500 \mathrm{kgN} / \mathrm{km}^{2} /$ year (A-H, Table $1 \mathrm{~b}$, c), i.e., more than half the amount currently exported by the three basins combined (Table 1a). When looking into the details, however, one can see that the present requirements in animal proteins for human consumption would not be covered by our organic farming scenario, which would still require the importation of $42-60 \%$ of the current needs of meat and milk (respectively for the two OA scenarios and the three basins combined), compared with $50 \%$ in the current situation. This persisting requirement of longdistance importation of meat and milk clearly emphasises the unsustainability of the increasing share of animal proteins in the modern human diet, presently representing as much as $65 \%$ of total protein consumption in France and Belgium. Results of our organic scenarios are highly sensitive to any hypothetic change in human diet. It can be calculated that the percentage of animal to total proteins in human diet required for our two OA scenarios (respectively 6 and $3 \mathrm{mg} / \mathrm{l}$ ) allowing self-sufficiency of the combined three basins for meat and milk consumption would be $39-28 \%$, i.e., about half the current value in France and Belgium. This is in line with the so-called demitarian option (a diet with half the current proportion of meat) recently advocated by a group of European scientists (http:// www.nine-esf.org/barsac-declaration). This also represents the current rate in most Mediterranean countries [(Italy $54 \%$, Tunisia 27\%, Turkey 25\% (FAOstat 2006)].

Regarding the ecological functioning of the three river systems, our results clearly show that a shift to organic 
agriculture allows reaching much lower nitrate concentrations in surface water than any other mitigation measures. It is the only scenario able to bring the nitrogen concentration in most rivers from the three basins below the level of $2.25 \mathrm{mgN} / \mathrm{l}\left(10 \mathrm{mgNO}_{3} / \mathrm{l}\right)$, which is often considered a threshold for a good ecological status (Camargo and Alonso 2006).

At the coastal zones, this scenario also more than halves the nitrogen delivery with respect to the good agriculture practice scenario. Judging from the N-ICEP calculation, this is not enough, unfortunately, to eliminate all risk of harmful algal blooms in the receiving coastal waters; the risk is, however, very significantly reduced. Application of the MIRO model (Lancelot et al. 2009; C. Lancelot et al., unpublished) predicts that the maximum cell density of Phaeocystis blooms in the Belgian coastal zones would be reduced from $46 \times 10^{6}$ cells/ 1 in the present situation to $21-30 \times 10^{6}$ cells/l in our organic agriculture scenario, while the duration of the blooms would be reduced from 33 days to 18 and 25 days, respectively, for the two OA scenarios and for similar hydrological conditions (those of the year 2000). By comparison, the corresponding figures for the scenario of good agricultural practices are $35 \times 10^{6}$ cells/l for 27 days.

We are aware that our generalised organic farming scenario is certainly not a realistic short-term objective. Presently, organic farming only concerns $3.9 \%$ of the total agricultural area in Europe, with, however, large disparities between countries, from $11 \%$ in Austria to only $2 \%$ in France (Bonny 2006). However, on the consumer side, the demand for food produced from organic farming is rapidly growing, by $10-15 \%$ per year in recent periods (Bonny 2006). This also might plead in favour of extending this mode of agriculture in the future, which over the long term appears to be the only way to preserve water resources while meeting the population's food requirements.

Finally, coming back to the issue of the capability of organic farming to "feed the world", we must admit that, compared to the current situation, our OA scenarios imply that the fertile areas of the Parisian Basin would decrease their capacity for exporting agricultural products to other, less fertile areas. It is outside the scope of the present paper to discuss the consequences at the global scale of such a restricted offer from highly productive areas. Note, however, that many authors consider that malnutrition problems in the world originate from the economic disequilibrium created by the global offer of low price basic agricultural goods from industrialised countries, preventing small farmers in many poor countries to invest in more efficient techniques (Mazoyer 2001). In the global scenarios established by the Millennium Ecosystem Assessment, the Adapting Mosaic option, which depicts a world developing locally based ecosystem management strategies with simple technologies privileging local economic circuits, predicts much less food shortage, particularly in Africa and South America, than the 'Business as Usual' Global Orchestration scenario which maximises the development of international trade (Billen et al. 2010).

Acknowledgments This study was carried out within several research programs, namely the Thresholds and AWARE projects, supported by the European Commission, the TIMOTHY network, funded as an Interuniversity Attraction Poles (Phase VI) by the Belgian Science Policy, the PIREN-Seine Program, funded, a.o. by the Agence de l'Eau Seine-Normandie. It profited from the discussions made possible through the ESF NinE Research Network.

Open Access This article is distributed under the terms of the Creative Commons Attribution Noncommercial License which permits any noncommercial use, distribution, and reproduction in any medium, provided the original author(s) and source are credited.

\section{References}

Agreste (2000) Ministère de l'agriculture et de la pêche, Agreste recensement agricole de l'année 2000. (http://www.agreste. agriculture.gouv.fr/)

Badgley C, Perfecto I (2007) Can organic agriculture feed the world? Renew Agric Food Syst 22:80-86

Badgley C, Moghtader J, Quintero E, Zakem E, Chappell M, AvilesVazquez K, Samulon A, Perfecto I (2007) Organic agriculture and the global food supply. Renew Agric Food Syst 22:86-108

Benoît M, Larramendy S (2003) Agriculture biologique et qualité des eaux : Depuis des observations et enquêtes à des tentatives de modélisation en situation de polyculture-élevage. Séminaire sur les recherches en Agriculture Biologique INRA. ACTA Draveil, 20 et 21 novembre 2003

Benoît M, Saintot D, Gaury F (1995) Mesures en parcelles d'agriculteurs des pertes en nitrates. Variabilité sous divers systèmes de culture et modélisation de la qualité de l'eau d'un bassin d'alimentation. C R Acad Agric Fr 81:175-188

Billen G, Garnier J (2007) River basin nutrient delivery to the coastal sea: assessing its potential to sustain new production of non siliceous algae. Mar Chem 106:148-160

Billen G, Garnier J, Ficht A, Cun C (2001) Modeling the response of water quality in the Seine River estuary to human activity in its watershed over the last 50 years. Estuar Coasts 24:977-993

Billen G, Garnier J, Rousseau V (2005) Nutrient fluxes and water quality in the drainage network of the Scheldt basin over the last 50 years. Hydrobiologia 540:47-67

Billen G, Garnier J, Nemery J, Sebilo M, Sferratore A, Benoit P, Barles S, Benoit M (2007) A long term view of nutrient transfers through the Seine river continuum. Sci Total Environ 275:80-97

Billen G, Thieu V, Garnier J, Silvestre M (2009a) Modelling the N cascade in regional watersheds: the case study of the Seine, Somme and Scheldt rivers. Agric Ecosyst Environ 133:234-246

Billen G, Barles S, Garnier J, Rouillard J, Benoit P (2009b) The foodprint of Paris: long term reconstruction of the nitrogen flows imported to the city from its rural hinterland. Reg Environ Change 9:13-24. doi:10.1007/s10113-008-0051-y

Billen G, Beusen A, Bouwman L, Garnier J (2010) Anthropogenic nitrogen autotrophy and heterotrophy of the world's watersheds: past, present, and future trends, Global Biogeochem, Cycles, 24 , GB0A11, doi:10.1029/2009GB003702 
Bonny S (2006) L'agriculture biologique en Europe: situation et perspectives. Notre Europe (http://www.notre-europe.eu/ fileadmin/IMG/pdf/Bonny_Agribio.pdf)

Camargo J, Alonso Á (2006) Ecological and toxicological effects of inorganic nitrogen pollution in aquatic ecosystems: a global assessment. Environ Int 32:831-849

Connor D (2008) Organic agriculture cannot feed the world. Field Crops Res 106:187-190

Diaz RJ, Rosenberg R (2008) Spreading dead zones and consequences for marine ecosystems. Science (Washington) 321:926-929

Drinkwater LE, Wagoner P, Sarrantonio M (1998) Legume-based cropping systems have reduced carbon and nitrogen losses. Nature 396:262-265

Directive 2000/60/EC (2000) Directive 2000/60/EC of the European Parliament and of the council of 23 October, 2000 establishing a framework for community action in the field of water policy. Off $\mathrm{J}$ Eur Commun

FAOstat (2006) Food and Agriculture Organization of the United Nations. Statistical Database

FranceAgriMer (2009) Situation des marchés des céréales biologiques, campagne 2008/2009 (http://www.onigc.fr/pdf/FR/cer0509.pdf)

Glachant C (2009) Resultats technico-economiques en systèmes de grandes cultures biologique en zone centre-Recolte 2007. Journal Technique Grandes Culture biologique ITAB/Arvalis

Hansen B, Kristensen E, Grant R, Høgh-Jensen H, Simmelsgaard S, Olesen J (2000) Nitrogen leaching from conventional versus organic farming systems - a systems modelling approach. Eur J Agron 13:65-82

Honish M, Hellmeier C, Weiss K (2002) Response of surface and subsurface water quality to land use changes. Geoderma 105: 277-298

Korsaeth A, Eltun R (2000) Nitrogen mass balances in conventional, integrated and ecological cropping systems and the relationship between balance calculations and nitrogen runoff in an 8-year field experiment in Norway. Agric Ecosyst Environ 79:199-214

Lancelot C, Spitz Y, Gypens N, Ruddick K, Becquevort S, Rousseau V, Lacroix G, Billen G (2005) Modelling diatom and Phaeocystis blooms and nutrient cycles in the Southern Bight of the North Sea: the MIRO model. Mar Ecol Prog Ser 289:63-78

Lancelot C, Gypens N, Billen G, Garnier J, Roubeix V (2007) Testing an integrated river-ocean mathematical tool for linking marine eutrophication to land use: the Phaeocystis-dominated Belgian coastal zone (Southern North Sea) over the past 50 years. J Mar Syst 64:216-228

Lancelot C, Rousseau V, Gypens N (2009) Ecologically based indicators for Phaeocystis disturbance in eutrophied Belgian coastal waters (Southern North Sea) based on field observations and ecological modelling. J Sea Res 61:44-49

Ledoux E, Gomez E, Monget JM, Viavattene C, Viennot P, Ducharne A, Benoit M, Mignolet C, Schott C, Mary B (2007) Agriculture and groundwater nitrate contamination in the Seine basin. The STICS-MODCOU modelling chain. Sci Total Environ 375:33-47

Mazoyer M (2001) Protecting small farmers and the rural poor in the context of globalization. Food and Agriculture Organization of the United Nations, Rome $23 \mathrm{pp}$

Mignolet C, Schott C, Benoît M (2007) Spatial dynamics of farming practices in the Seine basin: methods for agronomic approaches on a regional scale. Sci Total Environ 375:13-32

NIS (2000) Agricultural census 2000, results database. (http://www. statbel.fgov.be/)

OSPAR (2005) Common Procedure for the identification of the eutrophication status of the OSPAR Maritime Area, OSPAR Agreement 2005-3

Redfield AC, Ketchum BH, Richards FA (1963) The influence of organisms on the composition of sea-water. In: Hill MN (ed) The sea. Wiley, New York, pp 12-37

Ruelland D, Billen G, Brunstein D, Garnier J (2007) SENEQUE 3: a GIS interface to the RIVERSTRAHLER model of the biogeochemical functioning of river systems. Sci Total Environ 375:257-273

Sabatier P (1890) Leçons élémentaires de chimie agricole par Paul Sabatier. G. Masson, Paris, p 339

Stanhill G (1990) The comparative productivity of organic agriculture. Agric Ecosyst Environ 30:1-26

Thieu V, Billen G, Garnier J (2009) Nutrient transfer in three contrasting NW European watersheds: the Seine, Somme, and Scheldt Rivers. A comparative application of the Seneque/ Riverstrahler model. Water Res 43:1740

Thieu V, Garnier J, Billen G (2010) Assessing the effect of nutrient mitigation measures in the watersheds of the Southern Bight of the North Sea. Sci Total Environ 408:1245-1255 